\begin{tabular}{|l|l|l|l|}
\hline Natura Somogyiensis & $\mathbf{3}$ & $35-43$ & Kaposvár, 2002 \\
\hline
\end{tabular}

\title{
Bogárközösségek (Coleoptera) vizsgálata pionir és rekultivált élőhelyen
}

\author{
SÁR JÓZSEF ÉS DUDÁS GYÖRGY
}

SÁR J. \& DudÁs GY.: A study of beetle assembledges on pioneer and re-cultivated habitats (Coleoptera) Abstract: The survey of Coleoptera assembledges living on the uranium waste-heap of Kővágószőlős (Baranya County) was carried out in 1994 and in 2001. This study presents the collected species before (14 families, 53 species) and after (19 families, 79 species) the re-cultivating process.

\section{Bevezető}

Az 1950-es évek közepétől a Nyugat-Mecsekben kibontakozó nagyüzemi uránbányászat és az általa megmozgatott hatalmas mennyiségü kőzet felszínre hozatala megváltoztatta a déli hegyoldalak, lejtők felszíni környezetét. Az évtizedek alatt felhalmozódott meddő-kőzet hányói, valamint az ércdúsító segédüzeme zagytározói kialakításával elsősorban Kővágószőlős közelében jelentkeztek a legkárosabb hatások az eredeti környezetre.

Az 1994-ben végzett bogarászati kutatások a legnagyobb tömegű meddőhányó, a kővágószőlősi III. számú uránbánya környékére irányultak, melynek eredményeit, SÁR és SzIRTES (1994) kéziratban közli. A mecseki uránérc-bányák esetenként millió $\mathrm{m}^{3}$-es nagyságrendű meddőhányói természeti képének, a környezetre gyakorolt hatásának, és a rovarvilágának kutatása, csak az 1990-es évektől lett engedélyezett. Korábban ,állambiztonsági érdekek" végett semmiféle adat, fénykép vagy térkép nem állhatott rendelkezésünkre. A Jakab-hegy déli lejtőjén fekvő kb. 200 m magas meddőhányó rekultivációját követően indokolttá vált a terület ismételt bogarászati felmérése.

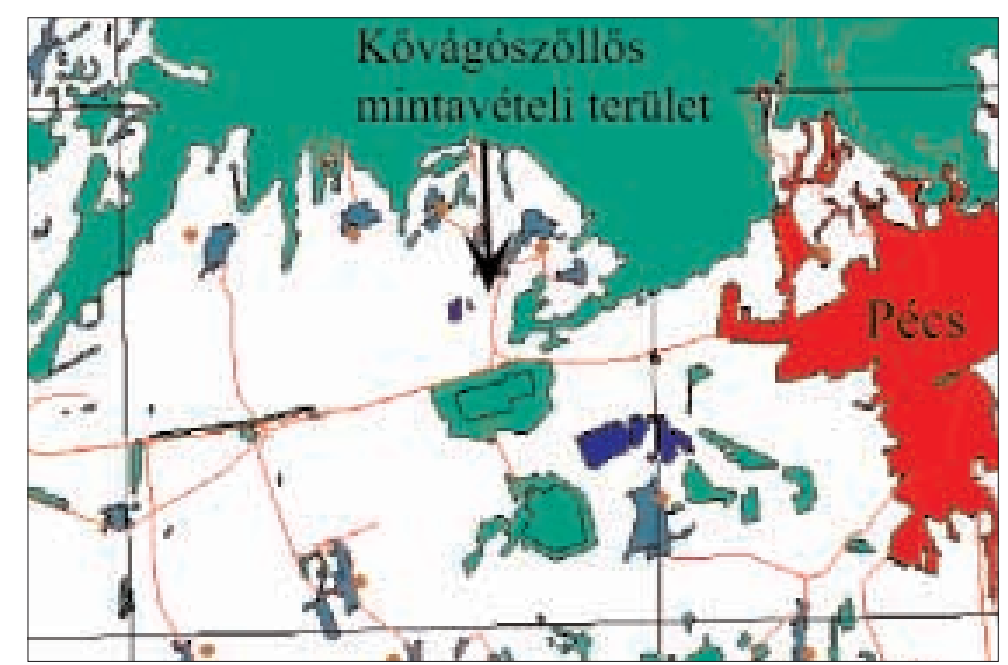

1. ábra: A meddőhányó helyzete Kővágószőlősön 


\section{Anyag és módszer}

A gyűjtéseket melyek mintavétel jellegűek voltak 2001. V. 15. - IX. 22. között végeztük, hasonlóan az 1994-es vizsgálatokhoz. Elsősorban talajcsapdázással folytak a gyüjtések, kisebb mértékben egyeléssel. Az etilén-glikolos talajcsapdákat (20 db.) a rekultivált meddőhányó tövétől a csúcsáig egy vonal mentén kb.: 5 m-enként telepítettük. Egyeléssel elsősorban a meddőhányó tövénél kialakított vízelvezető árokban és környékén gyüjtöttünk. Az így előkerült 19 bogárcsalád, 74 faját dolgoztuk fel.

\section{A meddőhányó és a környező terület természeti viszonyainak leírása.}

A meddőhányót alkotó kőzet elsősorban Perm és alsó Triász korú vörös homokkő, mely a különböző mélységü bányaaknákból kerültek felszínre. A hegynyi kőzethalmaz lábánál korábban megfigyelt vizes területek, a rekultivációt követően eltűntek, melyek részben eredeti, másfelől a bányászati tevékenységek hatására jöttek létre. Ennek eredményeként eltűntek a területről a kisebb sásos-nádas foltok. Feljebb haladva a kopár, talajréteggel sem borított területek megszüntek, helyettük benövényesült élőhelyek találhatók. A rekultiváció során telepített tölgyfákon (Quercus petrea) kívül, megjelentek egyéb fás-, és lágyszárú növények pl.: kökény (Prunus spinosa), galagonya (Crataegus monogyna), vadrózsa (Rosa canina), siska nádtippan (Calamagrostis epigeios), kék katángkóró (Cichorium intybus), ökörfark kóró (Verbascum sp.), közönséges aszat (Cirsium vulgare), orvosi somkóró (Melilotus officinalis), parlagfü (Ambrosia elatior) stb., föleg gyomok.

A meddőhányó és környezete a Mecsek-hegység Jakab-hegyének déli oldalára jellemző xerotherm területek, melyekre a következő növénytársulások a jellemzők:

Növényföldrajzi tagolás tekintetében a Nyugat-Balkáni flóratartomány pécsi (Sopianicum) flórajárásba tartozik. Cseres-tölgyesek (Quercetum petraeae-cerris), és a meredek köves oldalakon sziklaerdők (Tilia argenteae-Fraxinetum) találhatók, melyeket gazdag aljnövényzetü karsztbokorerdők (Inulo siraeifoliae-Quercetum pubescentis) tesznek változatossá.

A Jakab-hegy déli kitettségű oldalaira a következő éghajlati adottságok a jellemzőek: szubmediterrán jellegű mérsékelten meleg, és mérsékelten nedves területek. A hőmérséklet átlaga $10.0^{\circ} \mathrm{C}$ körüli, a nyári félév átlaghőmérséklete pedig $16.5^{\circ} \mathrm{C}$. A fagymentes időszak hossza átlagosan 198 nap (április 15. - október 30.-ig). A legmagasabb nyári hőmérsékletek átlaga $33.0{ }^{\circ} \mathrm{C}$ közelében van. Az évi csapadék összege $680-730 \mathrm{~mm}$ között mozog.

A rekultivációt megelőzően a meddőhányó felszínéhez közel eső részen $(30 \mathrm{~cm})$ erős sugárzást lehetett észlelni (U. RA.). A tájrendezés során a területet vastag betonlap és talajréteg takarást kapott, mely hatására a sugárzás jelentősen csökkent.

Az előkerült bogárfajok (Coleoptera) azonosítása során, semminemü morfológiai, szín-, és alakváltozási jelet, mutációkat nem észleltünk, a korábbi és jelen vizsgálat során sem. 


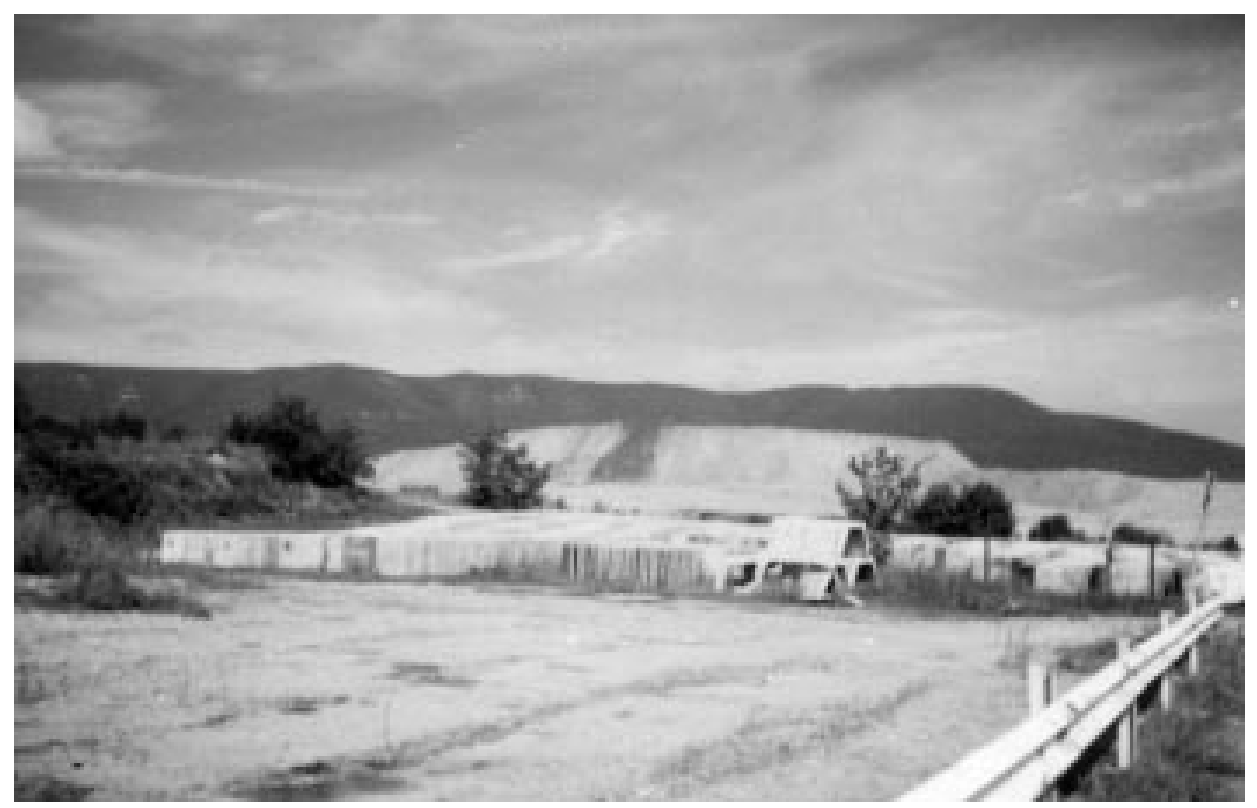

2. ábra: A meddőhányó 1994-ben készített látképe

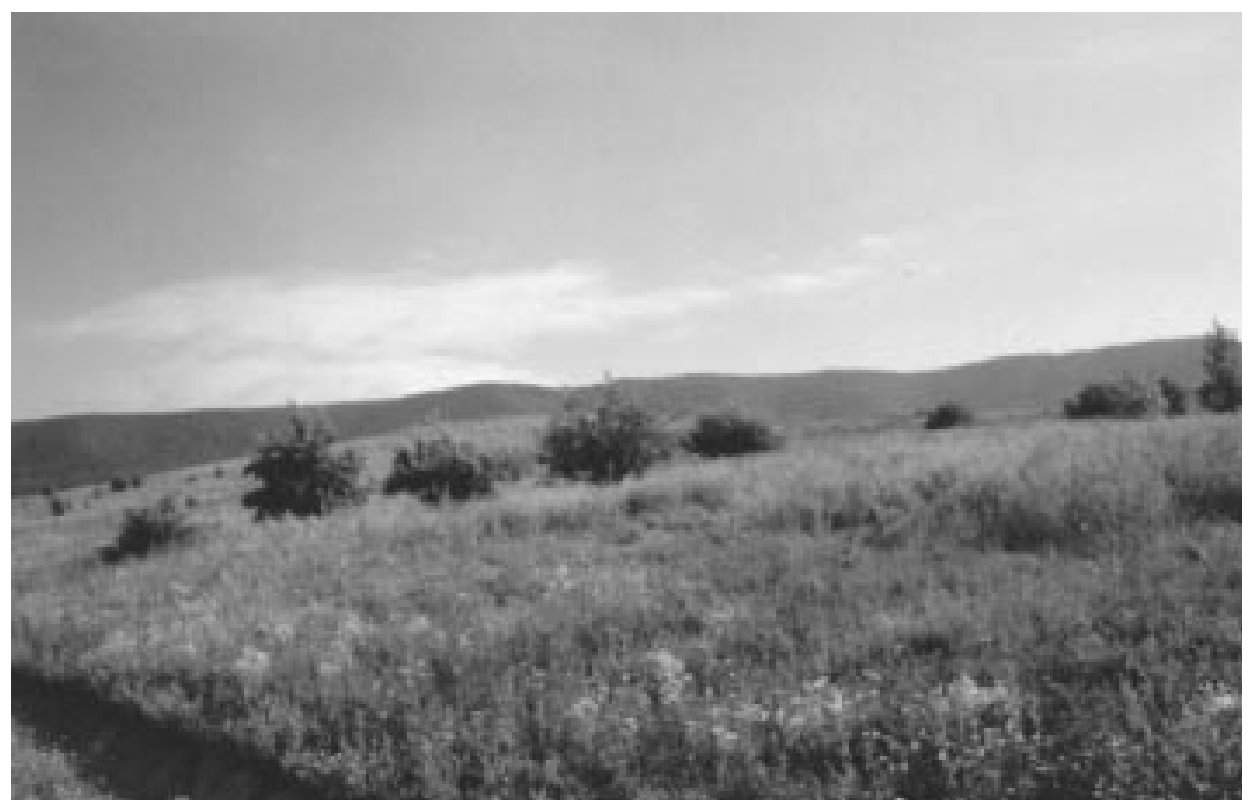

3. ábra: A meddőhányó 2001-ben készített látképe 


\section{Az előkerült fajok jegyzéke}

A bogarak (Coleoptera) rendszertani sorrendjét a korábban is használt WILHELM H., LUCHT (1987) munkája alapján közöljük.

Továbbiakban ismertetjük a gyüjtött fajokat, megadjuk a gyüjtőmódszert és a gyüjtők nevét, ez utóbbi kettőt rövidítve, továbbá a példányszámokat.

A gyüjtés módszerének rövidítése:

e.- egyelés

tcs.- talajcsapda

A gyüjtők nevének rövidítése:

S.-SZ.- Sár József - Szirtes Bálint

S.-D.- Sár József - Dudás György

Az alábbiakban külön közöljük mindkét vizsgálat (1994. V. 15. - IX. 22. és a 2001. V. 15. - IX. 22.) eredményeit.

\section{A rekultivációt megelőző kutatások adatai (1994)}

Cicindelidae

Cicindela silvicola (Dej.) e., 1 pld. S.-Sz.

\section{Carabidae}

Carabus coriaceus (L.) e., 1 pld. S.-Sz.

Carabus ullrichi (Germ.) e., 2 pld. S.-Sz.

Harpalus dimidiatus (Rossi) e., 3 pld. S.-Sz

Harpalus rubripes (Duft.) e., 2 pld. S.-Sz.

Harpalus tardus (Panz.) e., 2 pld. S.-Sz.

Pterostichus vulgaris (L.) e., 2 pld. S.-Sz.

Calathus erratus (Sahl.) tcs., 25 pld.

Calathus melanocephalus (L.) tcs., 3 pld.

\section{Histeridae}

Hister quadrimaculatus (L.) e., 2 pld. S.-Sz.

Silphidae

Thanatophilus rugosus (L.) e., 4 pld. S.-Sz.

\section{Staphylinidae}

Paragabrius fumarius (Grav.) tcs., 4 pld.

Ouchemus caesarous (Crev.) tcs., 2 pld.

Quedius meridiocarpaticus (Smel.) tcs., 4 pld

Quedius fuliginosus (Grav.) tcs., 7 pld.

Oecypus olens (Müll.) tcs., 25 pld.

Oecypus biharicus (Müll.) tcs., 11 pld.

Preudocypus mus (Braille) tcs., 9 pld.

Platyorosus stercorarius (O1.) tcs., 7 pld.

Bisnius umbrinus (Er.) tcs., 1 pld.

\section{Buprestidae}

Anthaxia nitidula (L.) e., 1 pld. S.-Sz.
Acmaedera flavofasciata (Pill.) e., 1 pld. S.-Sz.

Trachys pumilus (Ill.) tcs., 1 pld.

\section{Nitidulidae}

pld.

Glischrocharis quadrisignatus (Say.) tcs., 11

Endomychidae

Lycoperdina succinata (L.) tcs., 2 pld.

Anthicidae

Anthichus hispidus (Rossi) tcs., 4 pld.

\section{Tenebrionidae}

Gnaptor spinimanus (Pall.) e., 3 pld. S.-Sz

Opatrum sabulosum (L.) e., 3 pld. S.-Sz.

Gonocephalum pusillum (Fabr.) tcs., 2 pld.

Scarabaeoidae

Geotrupes stercorosus (Scriba) e., 1 pld. S.-Sz.

\section{Melolonthidae}

Pentodon idiota (Herbst) e., 3 pld. S.-Sz. Epicometis hirta (Poda) e., 9 pld. S.-Sz.

Oxythyrea funesta (Poda) e., 4 pld. S.-Sz.

Cetonia aurata (L.) e., 2 pld. S.-Sz.

Valgus hemipterus (L.) e., 1 pld. S.-Sz.

\section{Cerambycidae}

Acmeops collaris (L.) e., 2 pld. S.-Sz. Strangalia maculata (Poda) e., 7 pld. S.-Sz.

Judolia cerembyciformis (Schrank) e., 3 pld. S.-Sz. 
Judolia erratica (Dalm.) e., 10 pld. S.-Sz. Leptura livida (Fabr.) e., 10 pld. S.-Sz. Strangalia melanura (L.) e., 3 pld. S.-Sz. Strangalia nigra (L.) e., 4 pld. S.-Sz. Strangalia septempunctata (Fabr.) e., 5 pld. S.-Sz. Stenopterus rufus (L.) e., 9 pld. S.-Sz.

\section{Curculionidae}

Otiorhynchus duinensis (Germ.) tcs., 1 pld.
Otiorhynchus dubius (Ström.) tcs., 1 pld. Otiorhynchus ligustici (L.) tcs., 2 pld. Sitonia langula (Gyll.) tcs., 2 pld. Sitonia hispidula (Fabr.) tcs., 2 pld. Sitonia humeralis (Steph.) tcs., 2 pld. Sitonia lineatus (L.) tcs., 1 pld. Alophus triguttatus (Fabr.) tcs., 2 pld. Trachyphloeus laticollis (Bohem) tcs., 2 pld

\section{A rekultivációt követő kutatások adatai (2001)}

\section{Cicindelidae}

Cylindera germanica (L.) tcs., 18 pld.

\section{Carabidae}

Calosoma auropunctatus (L.) tcs., 1 pld. Carabus coriaceus (L.) tcs., 1 pld. Harpalus pubescens (Müll.) tcs., 1 pld. Harpalus dimidiatus (Rossi) tcs., 4 pld. Harpalus rubripes (Duft.) tcs., 2 pld. Harpalus tardus (Panz.) tcs., 3 pld. Pterostichus melas (Creutz.) tcs., 18 pld. Abax ater (Pill.) tcs., 2 pld. Calathus fuscipes (Goeze) tcs., 5 pld Amara convexior (Steph.) tcs., 5 pld. Brachinus crepitans (L.) tcs., 2 pld.

\section{Histeridae}

Hister quadrimaculatus (L.) tcs., 13 pld. Saprinus semistriatus (Scriba) tcs., 1 pld. Hypocacculus rufipes (Kugl.) tcs., 1 pld.

\section{Shilphidae}

Shilpha obscura (L.) tcs., 1 pld. Ablattaria laevigata (Fabr.) tcs., 4 pld. Thanathophilus sinuatus (Fabr.) tcs., 15 pld. Necrophorus humator (L.) tcs., 1 pld. Necrophorus vespillo (L.) tcs., 2 pld.

\section{Staphylinidae}

Oecipus olens (Müll.) tcs., 1 pld.

Oecipus biharicus (Müll.) tcs., 1 pld.

Platytracus chalcocephalus (Fabr.) tcs., 4 pld.

\section{Elateridae}

Drasterius bimaculatus (L.) tcs., 12 pld. Cardiophorus rufipes (L.) tcs., 11 pld Agriotes ustulatus (L.) tcs., 12 pld.

\section{Buprestidae}

Trachis troglodytes (Gill.) tcs., 1 pld.

\section{Byrrhidae}

Byrrhus pilula (L.) tcs., 5 pld., e., 4 pld. S.-D.

\section{Dermestidae}

Dermestes undulatus (L.) tcs., 1 pld. Dermestes ater (Fabr.) tcs., 1 pld.
Dermestes lardarius (L.) tcs., 1 pld

Dermestes cadaverinus (Fabr.) tcs., 1 pld.

\section{Nitidulidae}

Glischrocharis quadrisignatus (Say.) tcs., 6 pld.

Carpophilus bipustulatus (Heer.) tcs., 3 pld.

Coccinelidae

Coccinela 7-punctata (L.) e., 1 pld. S.-D.

Adonia variegata (Goeze) tcs., 2 pld.

Thea 22-punctata (Fabr.) tcs., 1 pld.

Scymnus auritus (L.) tcs., 1 pld.

Meloidae

Epicauta rufidorsum (Goeze) tcs., 4 pld., e., 3 pld. S.-D.

\section{Tenebrionidae}

Opatrum sabulosum (L.) tcs., 2 pld.

Crypticus quisquilius (L.) tcs., 4 pld.

Blaps abreviata (Mén.) tcs., 1 pld.

Trogidae

Trox hispidus (Pont.) tcs., 4 pld.

\section{Scarabaeidae}

Pleurophorus caesus (Creutz.) tcs., 2 pld.

Sysiphus shafferi (L.) tcs., 25 pld.

Onthophagus ovatus (L.) tcs., 16 pld.

Onthophagus ruficollis (L.) tcs., 8 pld.

\section{Melolonthidae}

Epicometis hirta (Poda) tcs., 1 pld.

Amphimallon soltitialis (L.) tcs., 2 pld.

Oxythyrea funesta (Poda) e., 4 pld. S.-D.

Cetonia aurata (L.) e., 2 pld. S.-D.

Potosia cuprea (Fabr.) e., 3 pld. S.-D.

Valgus hemipterus (L.) e., 1 pld. S.-D.

\section{Cerambycidae}

Stenopterus rufus (L.) e., 1 pld. S.-D.

Plagionotus floralis (Pall.) e., 2 pld. S.-D.

Chlorophorus varius (Müll.) e., 3 pld. S.-D

Judolia erratica (Dalm.) e., 10 pld. S.-D.

Judolia cerambyciformis (Shrank) e., 8 pld. S.-D.

Dorcadion fulvum (Scop.) tcs., 3 pld.

Dorcadion aetiops (Scop.) tcs., 1 pld. 


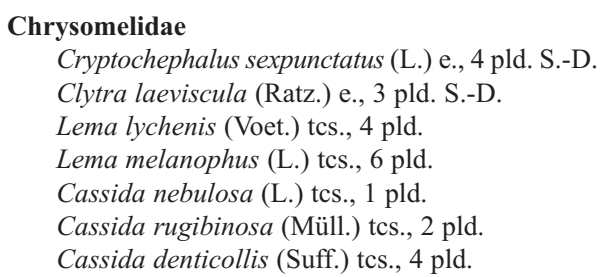

\author{
Curculionidae \\ Sitona crenata (Herbst.) tcs., 2 pld. \\ Cleonus piger (Scop.) tcs., 1 pld. \\ Cleonus alternans (Herbst.) 10 pld. \\ Larinus optosus (Gyll.) tcs., 1 pld. \\ Othiorynchus ovatus (L.) tcs., 1 pld. \\ Lixus elongatus (Goeze) tcs., 7 pld. \\ Sphenophorus striatopunctatus (Goeze) tcs., 1 pld.
}

\section{Az 1994-es felmérés jellemző és ritka fajai}

Acmaedera flavofasciata (Pill.)

Mediterrán faj, az imágó májustól augusztusig repül, a meleg napsütéses órákban. A lárva az elhalt tölgyfa kérge alatt fejlődik, ritkán gesztenye-, és bükkfában. A Mecsekből csak 1 régi adata ismert (GEBHART 1953). Ritka (FrEUDE, et. al. 1979).

Gnaptor spinimanus (Pall.)

Pontomediterrán faj, a Balkán-félszigeten és a Kárpát-medencében honos. Nálunk elsősorban a Nagyalföldön, és a Dunántúl sztyepp területein, kopár hegyoldalain fordul elő. Helyenként igen gyakori (KASZAB 1957). Jellegzetes faja a Jakab-hegy déli lejtöinek.

Opatrum sabulosum (L.)

Előfordul egész Európában, keleten Szibériáig, délen a Kaukázusig. Magyarországon az Alföld és az alacsonyabb hegy és dombvidék száraz sztyepp-rétein, és a kultúrterületeken mindenütt gyakori. Xerophil faj (KASZAB 1957).

Pentodon idiota (Herbst)

Pontusi faj, nálunk az alföldek, hegy és dombvidékek középkötött, kopár talajú területein él (ENDRŐDI 1956)

Strangalia bifasciata (Müll.)

Előfordul Európában, Kisázsiától Iránig, valamint Szibériában. A bogár májustól június végéig repül, főleg xerotherm hegyoldalak erdőszegélyein, virágokon található (KASZAB 1971). Gyakori és jellegzetes cincérfaja a területnek.

\section{Az újonan előkerült fajok}

Cylindera germanica, Calosoma auropunctatus, Carabus coriaceus, Harpalus pubescens, Pterostichus melas, Abax ater, Calathus fuscipes, Amara convexior, Brachinus crepitans, Saprinus semistriatus, Hypocacculus rufipes, Shilpha obscura, Ablattaria laevigata, Thanathophilus sinuatus, Necrophorus humator, Necrophorus vespillo, Platytracus chalcocephalus, Drasterius bimaculatus, Cardiophorus rufipes, Agriotes ustulatus, Trachis troglodytes, Byrrhus pilula, Dermestes undulatus, Dermestes ater, Dermestes lardarius, Dermestes cadaverinus, Carpophilus bipustulatus, Coccinela 7-punctata, Adonia variegata, Thea 22-punctata, Scymnus auritus, Epicauta rufidorsum, Crypticus quisquilius, Blaps abreviata, Trox hispidus, Pleurophorus caesus, Sysiphus shafferi, Onthophagus ovatus, Onthophagus ruficollis, Amphimallon soltitialis, Potosia cuprea, Plagionotus floralis, Chlorophorus varius, Dorcadion fulvum, Dorcadion aetiops, Cryptochephalus sexpunctatus, Clytra laeviscula, Lema lychenis, Lema melanophus, Cassida nebulosa, Cassida rubiginosa, Cassida denticollis, Sitona crenata, Cleonus piger, Cleonus alternans, Larinus optosus, Othiorynchus ovatus, Lixus elongatus, Sphenophorus striatopunctatus. 


\section{Az 2001-es felmérés jellemző és ritka fajai}

Cylindera germanica (L.)

Elterjedési területe Közép- és Dél-Európa, nyugat felé egészen Angliáig, Franciaországig és észak Spanyolországig terjed, kelet felé pedig Kisázsián át egészen Kínáig. Faunaterületünkön gyakori. Előszeretettel gabona- és burgonyaföldeken, valamint ugaron tartózkodik (SzÉKESSY 1958). Nagy példányszámú előkerülése e faj megtelepedését igazolja.

Epicauta rufidorsum (Goeze)

Előfordul Közép- és Dél-Európában. Hazánkban az Alföld és a dombvidék lakója, de a hegyvidék völgyeibe is benyomul. Gyakori, sőt helyenként tömegesen lép fel, s akkor a kultúrterületeken károkat tehet. (KASZAB 1956). Mivel az Epicauta fajoknak fejlődésükhöz sáskák petéire van szükségük, a sáskák pedig száraz réteken élnek tömegesen, így e faj megjelenése is a terület benövényesülését igazolja.

Crypticus quisquilius (L.)

A legészakibb tájak kivételével előfordul az egész Palearktikus régióban, keleten egészen Szibériáig és Mongóliáig. Faunaterületünkön mindenütt elterjedt. Száraz cserjéseket, köves hegy és domboldalakat kedveli (KASZAB 1957).

Blaps abreviata (Mén.)

Kelet-mediterrán faj, mely Szíriától Kisázsián és a Balkán félszigeten át a Bécsi medencéig fordul elő. Hazánkban a Dunántúl és az Ösmátra vonulatának irányában egészen a Sátoros-hegyekig előfordul. Száraz kopár hegyoldalak, sztyepp-rétek jellegzetes faja. (KASZAB 1957).

Sysiphus shafferi (L.)

Közép- és déleurópai faj, a Kárpát-medencében a dombos vidékeket részesíti előnyben (ENDRŐDI 1956). A talajcsapdákban tömeges előfordulását, részben megtelepedése, másrészt a csapdákban bomló szerves anyagok jelenléte okozta.

Dorcadion fulvum (Scop.)

Előfordul a Cseh-medencében, Ausztria keleti felében, a Kárpát-medencében, a Kisalföldön és a Nagyalföld nyugati felében. Magyarországon dombvidéken helyenként közönséges. Lárvája fügyökerek között él (KASZAB 1971). A barna gyalogcincér előfordulása is a füfélék megjelenésének köszönhető.

Dorcadion aetiops (Scop.)

Ausztria keleti részétől a Pannon-medencén át Romániáig, Bulgáriáig, és Macedónián át Albániáig elterjedt. Faunaterületünkön az alacsonyabb hegy- és dombvidéken megtalálható, az Alföldön ritka. Lárvája fügyökerek között él (KASZAB 1971). A Mecsekhegység - Jakab-hegy száraz, füves déli kitettségü domboldalainak jellegzetes gyalogcincér faja.

\section{Értékelés}

A III. számú kővágószőlősi urán meddőhányó rekultivációja, az 1994-ben feltárt bogárközösségre gyakorolt hatásai a következőek: Az újonnan elökerült 59 bogárfaj már számszerüleg is mutatja a területen végbement pozitív változásokat. A növénytelepítéssel, és a spontán megjelenő pionír növényekkel együtt, a fitophag fajok diverzitása növekedett (Cerambycidae: Dorcadion sp., Curculionidae, Chrysomelidae sp.). Ugyanakkor néhány kopár élőhelyeket kedvelő, xerophil faj (Gnaptor, Pentodon) eltünése figyelhető meg.

Az ilyen nagy méretű káros antropogén hatások, mint az uránbányászat következtében létre hozott meddőhányók, a rekultiváció ellenére is csak évtizedek múltán, mutatnak az eredetihez, jelen esetben a Mecsek: Jakab-hegy déli oldalaira jellemző természeti képet. 


\section{Összefoglalás, természetvédelmi vonatkozások}

A kővágószőlősi III. számú uránércbánya bogarászati vizsgálatai 1994. V. 15. - IX. 22. és 2001. V. 15. - IX. 22.-ig folytak. A kutatások során lehetőségünk nyílt egy a Jakab-hegy déli lejtőin található nem természetes eredetü urán-meddőhányó bogárvilágának rekultivációt megelőző és azt követő összehasonlítására. Az előkerült viszonylag kevés bogárfaj a tájmegújítást megelőző erős antropogén hatásoknak (külszíni bányamunkák, bányakárok, talaj- és felszíni vizek csökkenése, vízsszenyezés), másrészt a szórványos kutatásoknak és a xerotherm környezetnek tudhatók be. Az idei felmérések adataiból következtethetünk ugyan a rekultiváció pozitív hatásaira, de lényeges változások, a területre jellemző bogárfauna megtelepedése, véleményünk szerint csak hosszú idő elteltével lesz tapasztalható.

A Mecsek és környéke uránércbányászatának teljes megszünése következtében a kisebb meddőhányók, zagyterek rekultivációi befejeződtek vagy folyamatban vannak. A felszíni bányakárokon kívül, a talajvizek és források bányászati jellegü felhasználása (mélyfúrás, hütés, „Zsomp”-vizek) erős talajvízszint csökkenést és enyhe radioaktív szennyezést okozott. A meddőhányó körüli területek és települések közelében igen enyhe, az emberi szervezetre nem túl káros U és az Ra sugárzó anyagok hatásai még sokáig fognak érvényesülni.

Az elkövetkezendőkben a bogarászati vizsgálatok bizonyára még több, a területre jellemző és ritka fajok előkerülését eredményezik.

\section{Irodalom}

ENDRŐDI S. 1956: Lemezescsápú bogarak - Lamellicornia. Magyarország állatvilága. Fauna Hungariae (12.) IX. kötet, 4. füzet. Akadémiai Kiadó, Budapest. pp. 106-170.

ERDÖsI F. 1987: A társadalom hatása a felszínre, a vizekre és az éghajlatra a Mecsek, és tágabb környezetében. Akadémiai Kiadó, Budapest. pp. 49-53.

Freude H., Harde K. W., Lohse G. A. 1979: Die Käfer Mitteleuropas (Band 6). Goecke \& Evers Verlag, Krefeld. pp. 247.

HoRvatovich S. 1992: Liste der carabiden-arten (Coleoptera, Carabidae) Ungars, (Stand 1991). Janus Pannonius Múzeum Évkönyve 37. Pécs, 1993. pp. 5-12.

KASZAB Z. 1955: Felemás lábfejízú bogarak 1. - Heteromera I. Magyarország állatvilága. Fauna Hungariae (17.) IX. kötet, 1. füzet. Akadémiai Kiadó, Budapest. pp. 1-69.

KAsZAB Z. 1956: Felemás lábfejízú bogarak 3. - Heteromera III. Magyarország Állatvilága. Fauna Hungariae (15.) IX. kötet, 3. füzet. Akadémiai Kiadó, Budapest. pp. 16-17.

KASZAB Z. 1971: Cincérek - Cerambycidae. Magyarország állatvilága. Fauna Hungariae (106.) IX. kötet, 5. füzet. Akadémiai Kiadó, Budapest. pp. 1-283.

Lovász Gy. 1977: Baranya megye természeti földrajza. Baranya Megyei Levéltár, Pécs.

SÁR J., SziRTES B. 1994: A kővágószőlősi uránérc-meddőhányó bogarászati (Coleoptera) vizsgálata. Kézirat. SomogYi S. (1990): Magyarország kistájainak katasztere II. Magyar Tudományos Akadémia, Földrajzi Kutató Intézet. Budapest.

SzÉKESSY V. (1958): Homokfutrinkák - Cicindelidae. Magyarország állatvilága. Fauna Hungariae (34.) VI. kötet, 2. füzet. Akadémiai Kiadó, Budapest. pp. 21-22. 


\title{
A study of beetle assembledges on pioneer and re-cultivated habitats
} (Coleoptera)

\section{JÓZSEF SÁR \& GYÖRGY DUDÁS}

This paper focuses on the Coleoptera assembledges living on the pioneer and later recultivated habitat of the No. 3 uranium waste-heap of Kővágószőlős, Baranya County. The study of the analyzed material clearly shows the positive results of the re-cultivation process, such as the increasing diversity of species. However, it is also clear that the recovery of the insect fauna characteristic to the ambient areas might take decades. Further researches might result in the discovery of other rare species characteristic to the neighboring areas

\author{
Authors' addresses: \\ József SÁR \\ H-7973 Teklafalu \\ Fő u. 39. \\ HUNGARY \\ György DudÁs \\ Duna-Dráva National Park \\ H-7625 Pécs \\ Tettye tér 9. \\ HUNGARY
}

